\title{
Anthelmintic Activity of Nine Varieties of Cajanus cajan (L.) Millsp on Haemonchus contortus from Sheep
}

Faustin Parfait Koutouan ${ }^{1,2}$, Yapo Magloire Yapi, ${ }^{1,3}$, Souleymane Kande ${ }^{4}$, Eboua Narcisse Wandan ${ }^{1,2}$

10.18805/IJAR.B-1400

\begin{abstract}
Background: Internal parasitosis is the most important parasitism in small ruminants in tropical region. Synthetic anthelmintics are usually used for their control. Due to the emergence of resistance in worm population, the use of alternative methods such as plants bioactive molecules are developed. This study aimed at assessing anthelmintic activity of nine varieties of Cajanus cajan, a taniferous plant cultivated in West Africa.

Methods: Leaves of the nine varieties of Cajanus cajan were dried, ground and hydroacetonic extracts were obtained by cold maceration at a concentration of $60 \mathrm{mg} / \mathrm{ml}$. Live adult of Haemonchus contortus were obtained from sheep's stomach and exposed, in triplicate, to the following solutions: hydroacetonic extracts $(60 \mathrm{mg} / \mathrm{ml})$, hydroacetonic extracts $(60 \mathrm{mg} / \mathrm{ml})$ associated with polyvinylpyrrolidone (PVP) $(50 \mathrm{mg} / \mathrm{ml})$, Levamisole $(20 \mathrm{mg} / \mathrm{ml})$ and phosphate buffered saline (PBS) solution. Worm death time was recorded for each treatment. Result: Worms exposed to Levamisole recorded the shortest death time about $9.73 \pm 1.77 \mathrm{~min}$. The potent of the extracts induced worm death time of $64.83 \pm 4.73 \mathrm{~min}$ while the least efficient induced a death time of $156.50 \pm 23.20 \mathrm{~min}$. Worms in the PBS solution were still alive after 24 hours of exposure. These results indicated that the four varieties of $C$. cajan used in this study have promising wormicidal. Besides that, the effect of tannins were not the only compound responsible for the anthelmintic activity.
\end{abstract}

Key words: Condensed tannin, Helminthosis, Hydroacetonic extracts, Polyphenols, Small ruminants, Taniferous plant.

\section{INTRODUCTION}

In tropical regions, internal parasitosis are the most important parasitism in small ruminants which constrain animals' survival and productivity (Mahieu et al., 2009, Krecek and Waller, 2006). Their high frequency causes significant economic losses in small ruminant breeding (HounzangbeAdote et al., 2005). Synthetic anthelmintics are used usually to control these parasitosis (Hoste et al., 2006). However, requests for a reduction of their use are more and more recurrent (Jackson and Miller, 2006), due to the emergence of resistance in worm population, their ecotoxicity and residues presence in animal products (Hoste et al., 2006; Krecek and Waller, 2006, Papadopoulos, 2008). For this purpose, alternative and or complementary methods are developed to control this gastrointestinal parasitism. Plant bioactive molecules use is one of these methods (Jackson and Miller, 2006; Githiori et al., 2006; Meenakshisundaram et al., 2017).

Cajanus cajan L., is an important legume forage (Kaboré et al., 2016; Sarkar et al., 2020) with several species (Sawargaonkar et al., 2016; Talari and Shakappa, 2018) which are medicinal plants containing tannins. Traditional varieties of this species have a long development cycle (711 months) (Velay et al., 2001) allowing sheep whose diet is composed of 20 to $50 \%$ ligneous and sub-ligneous species in the savannah (Bodji et al., 1996; César and Zoumana, 1999) to have feed during the dry season. Odeny (2007) reported that $C$. cajan forage increased roughage consumption, which resulted in a high live weight of the
${ }^{1}$ Institut National Polytechnique-Félix Houphouët Boigny de Yamoussoukro, BP 1093 Yamoussoukro, Côte d'Ivoire.

${ }^{2}$ Laboratoire Sciences Société and Environnement, UMRI Sciences Agronomiques et Génie Rurale, BP 1093 Yamoussoukro, Côte d'Ivoire.

${ }^{3}$ Département Agriculture et Ressources Animales, Laboratoire de Zootechnie et Productions Animales, BP 1313, Yamoussoukro, Côte d'Ivoire.

${ }^{4}$ Laboratoire National d'Appui au Développement Agricole/ Laboratoire Régional de Bouaké, BP 639 Bouaké 01, Côte d'lvoire.

Corresponding Author: Yapo Magloire Yapi, Institut National Polytechnique-Félix Houphouët Boigny de Yamoussoukro, BP 1093 Yamoussoukro, Côte d'Ivoire. Email: yapimagloire@yahoo.fr

How to cite this article: Koutouan, F.P., Yapi, Y.M., Kande, S. and Wandan, E.N. (2022). Anthelmintic Activity of Nine Varieties of Cajanus cajan (L.) Millsp on Haemonchus contortus from Sheep. Indian Journal of Animal Research. DOI: 10.18805/IJAR.B-1400.

Submitted: 18-06-2021 Accepted: 20-12-2021 Online: 16-01-2022

animals. In vitro action of Cajanus cajan on nematode is currently documented. This anthelmintic action has been attributed to phenolic compounds (Singh et al., 2010) such as tannins and flavonoids (Harris et al., 2014). Tannins play an important role in gastrointestinal parasitism control (Hoste et al., 2006; Williams et al., 2014), but this anthelmintic activity of the tannins depend on plant species (Hoste et al., 2006; Quijada et al., 2015). In addition, phenolic compounds vary according to Cajanus cajan varieties (Koutouan et al., 
2019). This in turn, could lead to a varietal difference in anthelmintic activity (Nguyen et al., 2005), as already noted by some authors in Sainfoin (Manolaraki, 2011; Azuhnwi, 2012). In previous anthelmintic tests performed with C. cajan, no indication was given on the varieties (Singh et al., 2010; Kaboré et al., 2016).

So, this study aimed to investigate the anthelmintic properties of nine varieties of Cajanus cajan against adult Haemonchus contortus from sheep and to elucidate the role of tannins in this activity.

\section{MATERIALS AND METHODS}

The study was carried out at the Institut National Polytechnique Félix Houphouët-Boigny (INP-HB) of Yamoussoukro (Côte d'Ivoire), from May 2018 to June 2019. The climate of the region is characterized by annual rainfall of 900 to $1100 \mathrm{~mm}$, temperatures ranging from $18^{\circ} \mathrm{C}$ to $35^{\circ} \mathrm{C}$ and a relative humidity between $75 \%$ and $85 \%$. Five improved varieties (ICPL 87 119-ASHA, ICP 8863-MARUTI, ICP 7035-KAMICA, ICPL 87119 GUIMU 3 (Asha), ICPL 332 ABAAYA), one Burkina Faso traditional variety (FKB-Red) and ivorian three traditional cultivars (white, red, black) of C. cajan, adapted of Côte d'Ivoire local agro-climatic conditions, were used in this study.

The characteristics of these varieties are described in Table 1. The plants were grown on the same site, under the same conditions. The leaves of these varieties were harvested at the early stage of ripening throughout the plant. Total polyphenols and tannins contents of the leaves were previously evaluated (Koutouan et al., 2019). The collected leaves were shade dried and ground into a fine powder using an electric blender. Then, the powders were stored in a dry and dark room at ambient temperature. Hydroacetonic extract was prepared by a cold maceration method using a $70 \%$ aqueous-acetone solution as previously described by Makkar (2000). The resulting mixture was suspended in an ultrasonic bath and sonicated for 30 minutes (two times 15 minutes) at room temperature. The obtained macerate was filtered and the extract was dried in an oven at $5^{\circ} \mathrm{C}$. The dry extracts were stored at $4^{\circ} \mathrm{C}$ until use.
Leaf extracts of the nine varieties of Cajanus cajan were evaluated for their ability to kill adult worms using the Adult Motility Assay (AMT). The AMT was conducted on mature $H$. contortus worms according to Eguale et al. (2006) technique. Live adult worms of $H$. contortus were collected from the abomasum of freshly slaughtered sheep at the national slaughterhouse of the city of Bouaké (Côte d'Ivoire). The worms were stored in a polypropylene bottle containing Phosphate Buffered Saline (PBS) solution. They were then immediately sent to the National Laboratory Office of Agricultural Development Support (LANADA, Côte-d'Ivoire) for anthelmintic tests. Six actively moving worms were exposed in triplicate to each of the four following treatments in separate Petri dishes at room temperature $\left(25-30^{\circ} \mathrm{C}\right)$ :

- Treatment 1: Hydroacetonic extracts at $60 \mathrm{mg} / \mathrm{mL}$ prepared in phosphate buffered saline (PBS) solution.

- Treatment 2: Hydroacetonic extract at $60 \mathrm{mg} / \mathrm{mL}$ with polyvinylpyrrolidone (PVP) at $50 \mathrm{mg} / \mathrm{ml}$ to selectively remove tannins in dissolved extracts (Williams et al., 2014), all prepared in PBS.

- Treatment 3: Levamisol at $20 \mathrm{mg} / \mathrm{ml}$, prepared in distiller water, according to Singh et al. (2010).

- Treatment 4: PBS (Negative control).

The death time ( $\mathrm{M}$, minutes) of the worms was chosen as a criterion of anthelmintic activity. It represents the time elapsed between contact with the extract solution and the moment when they lost their motility, evaluated by touching the worms with a clamp for five to six seconds.

A comparison of the mean time of death of adult worms for the different varieties was performed by one-way analysis of variance (ANOVA). The post hoc statistical significance test employed was Tukey HSD, differences between the means were considered significant at $P<0.05$. The effect of PVP on the wormicidal activities of leaf extracts was assessed using t-student test at $P<0.05$. Previously, when necessary, the data was transformed into a log (x) transformation to normalize the distribution. All statistical analyzes were performed using the $R$ software ( $R$ Development Core Team).

Table 1: Characteristics of the varieties and cultivars used.

\begin{tabular}{lcll}
\hline Varieties / Cultivars & Seed color & Origin of the seed & Nature of the varieties / cultivars \\
\hline White local cultivar (TCW) & White & Local market of Côte d'Ivoire & Local cultivar from Côte d'Ivoire \\
Red local cultivar (TCR) & Red & Local market of Côte d'Ivoire & Local cultivar from Côte d'Ivoire \\
Black local cultivar (TCB) & Black & Local market of Côte d'Ivoire & Local cultivar from Côte d'Ivoire \\
ICPL 87 119- ASHA (ICPLAS) & Red & INERA, Burkina Faso* & Improved variety \\
ICP 8863-MARUTI (ICPMA) & Red & INERA, Burkina Faso & Improved variety \\
ICP 7035-KAMICA (ICPKA) & Red & INERA, Burkina Faso & Improved variety \\
FKB-RED (FKBR) & Red & INERA, Burkina Faso & Local variety from Burkina Faso \\
ICPL 87 119 GUIMU 3 (Asha) (ICPLGA) & Red & INERA, Burkina Faso & Improved variety \\
ICPL 332 ABAAYA (ICPLAB) & Red & INERA, Burkina Faso & Improved variety \\
\hline
\end{tabular}

*INERA= Burkina National Institute for Environment and Agronomic Research. 


\section{RESULTS AND DISCUSSION}

\section{Anthelmintic effect of the nine varieties of cajanus cajan}

The extracts of the nine varieties of Cajanus cajan have been studied to assess their in vitro anthelmintic activity. A time-dependent response was observed with all the treatments (Fig 1). All the extracts showed an anthelmintic effect, although significantly lower compared to levamisol, as $100 \%$ of adult worms died after 60 to 200 min of exposure to the extracts while death occurred at 12 min for levamisol. Regarding PBS, no dead worm was found up to 24 hours after exposure. A significant effect $(P<0.05)$ was observed on the motility of adult $H$. contortus worms in all the leaves extracts. Moreover, according to their effects, the varieties used in this study can be grouped. Group one comprising four varieties (ICPL 87 119- ASHA, ICP 8863-MARUTI, ICP 7035-KAMICA and FKB-Red) are those with a higher average time of death $(156.50 \pm 23.20 \mathrm{mn}$ to $177.67 \pm 15.08$ $\mathrm{mn}$ ). Group two includes four other varieties (TC-White, TCBlack, ICPL 87119 GUIMU 3 (Asha) and ICPL 332 ABAAYA) with a medium average time of death $(98.60 \pm 35.76 \mathrm{mn}$ to $123.17 \pm 18.90 \mathrm{mn})$. The last group, represented by the traditional cultivar red (TC-Red), induced a low average time of death $(64.83 \pm 4.73 \mathrm{mn})$. The results of this study confirm the anthelmintic properties of Cajanus cajan, already reported by other authors (Singh et al., 2010; Kaboré et al., 2016). However, the average times of death recorded remained greater than the 17 minutes obtained by Singh et al. (2010) with hydroethanolic extracts $(40 \mathrm{mg} / \mathrm{ml})$ of $C$. cajan on Indian adult earthworms Pheretima posthuma and much less than the six hours obtained by Kaboré et al. (2016) on Haemonchus contortus with an aqueous extract of $C$. cajan at $100 \mathrm{mg} / \mathrm{ml}$. The anthelmintic effects of $C$. cajan are due, according to several authors, to the polyphenolic compounds present in the plant, notably tannins and flavonoids (Singh et al., 2010; Kaboré et al., 2016). These compounds found in the leaves are less polar and therefore are prone to dissolve in relatively less polar solvents, than water (Eguale et al., 2006). The work of Mohanty et al. (2011) showed a concentration of flavonoids in ethanolic extracts two to three times higher than in aqueous extracts. This explains the relatively long time (6 h) obtained by Kaboré et al. (2016) with aqueous extracts compared to those obtained in the present study and to that obtained by Singh et al. (2010). These facts indicate that in vitro anthelmintic effects of the same plant species and the same organ are variable depending on the solvent used. Although the mechanism of action of bioactive molecules involved in anthelmintic activity is still poorly understood. It is known that anthelmintic substances can reach the target worm by oral route or by diffusion, or absorption through the cuticle of the parasite, or a combination of both routes. But, the passive transfer of the drug by the cuticle is the predominant entry mechanism (Alvarez et al., 2007).

\section{Effects of polyvinylpyrrolidone on anthelmintic effects} of the extracts

Polyvinylpyrrolidone (PVP) at $50 \mathrm{mg} / \mathrm{ml}$ was used combined to hydroacetonic extract at $60 \mathrm{mg} / \mathrm{mL}$ to selectively remove tannins in dissolved extracts (Williams et al. 2014). The average time of death increased significantly $(p<0.05)$ for the varieties ICPL 87119 GUIMU 3 (Asha), FKB-Red, traditional red and black with the PVP addition in the hydroacetonic extracts. However, the others varieties did not experienced a significant $(p>0.05)$ increase in the time of death after PVP addition (Fig 2).

This result indicates that the tannins contained in the varieties of $C$. cajan in this study are not the only ones involved in the anthelmintic activity. Other secondary metabolites in these varieties certainly play an important

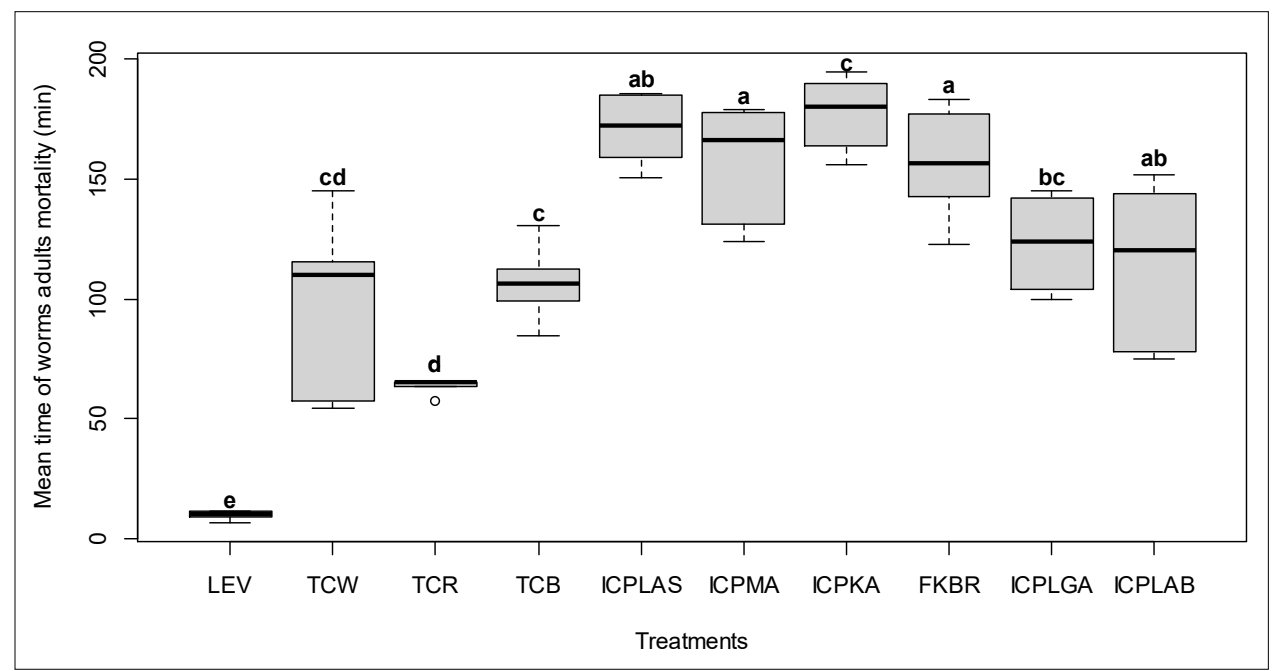

Fig 1: Graph showing in vitro anthelmintic activity (the time of death) of hydroacetonic extract at $60 \mathrm{mg} / \mathrm{mL}$ in comparison with positive control levamisol $(20 \mathrm{mg} / \mathrm{mL})(\mathrm{Lev})$. The time of death of the worms was used as the criterion for anthelmintic activity. Values shown are means, letter upper indicated significant difference from previous value at $\mathrm{P}<0.05$. 


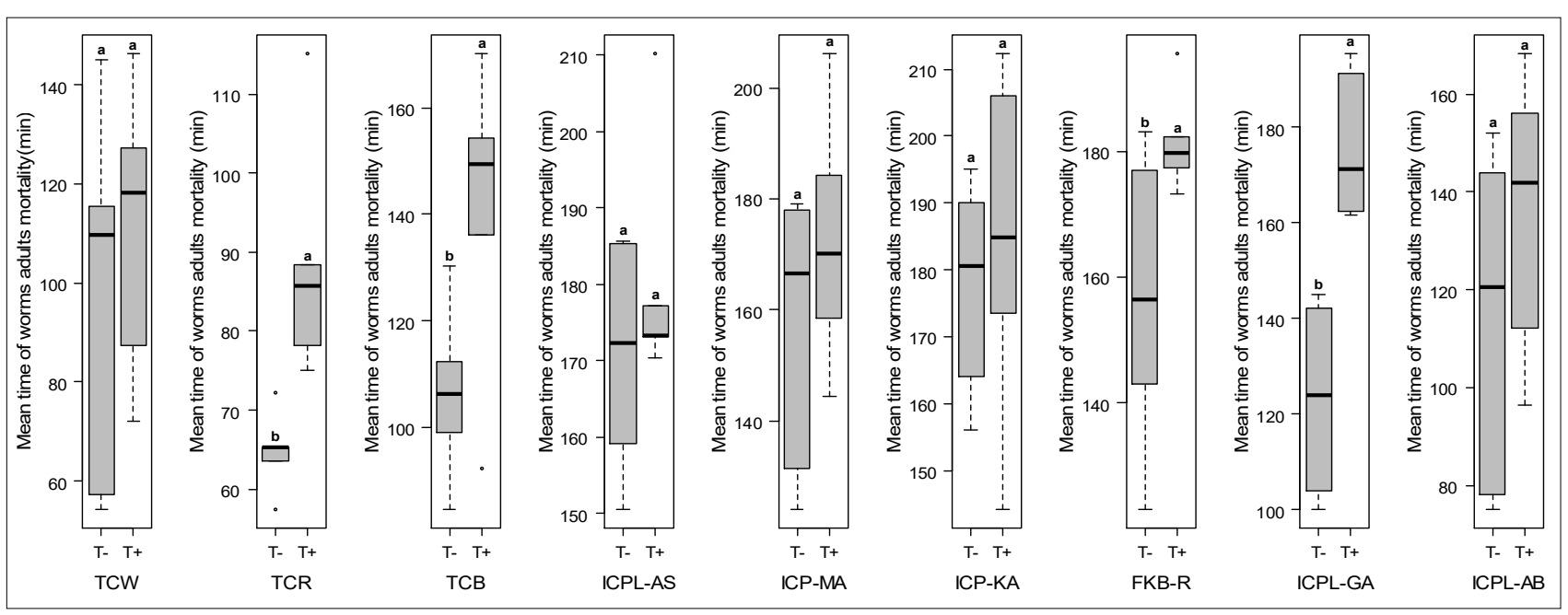

Fig 2: Graph showing in vitro mean anthelmintic activity (the time of death) of hydroacetonic extract at $60 \mathrm{mg} / \mathrm{mL}$ compared to combined hydroacetonic extract at $60 \mathrm{mg} / \mathrm{mL}$ with Polyvinylpyrrolidone (PVP) at $50 \mathrm{mg} / \mathrm{ml}$ on mature live Haemonchus contortus of sheep. The time of death of the worms was used as the criterion for anthelmintic activity. Values shown are means, letter upper indicated significant difference from previous value at $\mathrm{P}<0.05$. T- = no PVP; $\mathrm{T}+=$ with PVP.

role in anthelmintic actions. This could explain why the variety ICPL 332 ABAAYA showed a higher nematicidal efficacy than the varieties FKB-Red and ICPL 87 119-ASHA, while in a previous study, Koutouan et al. (2019) showed that the level of tannin of the first variety was very low compared to the seconds. These results confirmed the role of other secondary metabolites, apart from tannins, in the anthelmintic activity of plants, as already noted by Hoste et al. (2006) and Manolaraki (2011). The wormicidal activity hereby found could be due to flavonoids (Singh et al., 2010; Kaboré et al., 2016). Their content in the leaves of $C$. cajan is about 10 times that of tannins (Harris et al., 2014).

\section{CONCLUSION}

This study aimed to evaluate the anthelmintic activity of the leave extracts of nine varieties of Cajanus cajan a taniferous plant cultivated in West Africa. The results indicated that four of the varieties have promising wormicidal effect and that tannins were not the only ones responsible for this anthelmintic activity. However, an in vivo assay must be conducted in subsequent studies to confirm this result.

\section{ACKNOWLEDGEMENT}

The authors would like to thank the National Laboratory Office of Agricultural Development Support (LANADA, Côted'Ivoire) for performing the in vitro tests of this study.

\section{REFERENCES}

Alvarez, I.L., Mottier, L.M., Lanusse, E.C. (2007). Drug transfer into target helminth parasites. Trends in Parasitology. 23(3): 997-104. https://doi.org/10.1016/j.pt.2020.02.007.

Azuhnwi, N.B. (2012). Cultivar differences in nutritional and anthelmintic potential of Sainfoin (Onobrychis vociifolia) in ruminants. Doctoral Thesis, Univ. Hohenheim, Germany.
Bodji, N.C., Traore, D., Guerin, H. (1996). Comportement alimentaire du bétail (bovin, ovin et caprin) sur un pâturage de savanes arborées et arbustives guinéennes de Foro-Foro à Bouaké, Côte d'Ivoire. IDESSA, 32 p.

César, J., Zoumana, C. (1999) : Les régimes alimentaires des bovins, ovins et caprins dans les savanes de Côted'Ivoire, et leurs effets sur la végétation. Fourrages. 159 : 237-252. Available at: http://pascal-francis.inist.fr/vibad/ index. php?action=getRecordDetailandidt=1184754.

Eguale, T., Tilahun, G., Gidey, M., Mekonnen, Y. (2006). In vitro anthelmintic activities of four Ethiopian medicinal plants against Haemonchus contortus. Pharmacologyonline. 3: 153-165. DOI: 10.1002/0471141755.ph0547s40.

Githiori, J.B., Athanasiadou, S., Thamsborg, S.M. (2006). Use of plants in novel approaches for control of gastrointestinal helminths in livestock with emphasis on small ruminants. Veterinary Parasitology. 139(4): 308-320. https://doi.org/ 10.1016/j.vetpar.2020.109101.

Harris, K.K., Sahu, M., Verma D. (2014). Phytochemical analysis of the leaf, stem and seed extracts of Cajanus cajan L. (Dicotyledoneae: Fabaceae). World Journal of Pharmacy and Pharmaceutical Sciences. 3(8): 694-733.

Hoste, H., Jackson, F., Athanasiadou, S., Thamsborg, S.M., Hoskin S.O. (2006). The effects of tannin-rich plants on parasitic nematodes in ruminants. Trends in Parasitology. 22(6): 253-261. https://doi.org/10.1016/j.pt.2020.02.007.

Hounzangbé-Adoté, M.S., Paolini, V., Fouraste, I., Moutairou, K., Hoste H. (2005). In vitro effects of four tropical plants on three life-cycle stages of the parasitic nematode Haemonchus contortus. Res. Vet. Sci. 78: 155-160. https://doi.org/ 10.1016/j.rvsc.2020.03.028.

Jackson, F., Miller J. (2006). Alternative approaches to control-Quo vadit? Veterinary Parasitology. 139: 371-384. https:// doi.org/10.1016/j.vetpar.2020.109101. 
Kabore, A., Konate, A., Gnanda, B.I., Yougbare, B., Traore, A., Teguera, A.A., Diarra, S., Tamboura, H.H., Belem, A.M.G. (2016). Seed germination and anthelmintic activity of Cajanus cajan on sheep. Journal of Chemical and Pharmaceutical Research. 8(1): 403-410. www.jocpr.com

Koutouan, F.P., Yapi Y.M., Wandan E.N., Bodji N.C. and N'da K.P. (2019). Composition en polyphénols totaux et en tanins des feuilles de neuf variétés de Cajanus cajan (L.) Millsp. au cours du premier cycle de croissance et en fonction du mode d'exploitation. Int. J. Biol. Chem. Sci. 13(2): 882-898. http://dx.doi.org/10.4314/ijbcs.v9i2.47

Krecek, R.C. and Waller, P.J. (2006). Towards the implementation of the basket of options approach to helminth parasite control of livestock: Emphasis on the tropics/subtropics. Veterinary Parasitology. 139: 270-282. https://doi.org/ 10.1016/j.vetpar.2020.109095.

Mahieu, M., Arquet, R., Fleury, J., Coppry, O., Marie-Magdeleine, C., Boval, M., Archimède, H., Alexandre, G., Bambou, J.-C. and Mandonnet, N. (2009). Contrôle intégré du parasitisme gastro-intestinal des petits ruminants au pâturage en zone tropicale humide. Renc. Rech. Ruminants. 16: 265268. Conference: 16ème Rencontres Recherches Ruminants, INRA - Institut de l'Elevage At: Paris (France), Volume: http://www.journees3r.fr/lMG/pdf/2009_08_03_Mahieu.pdf

Makkar, H.P.S. (2000). Quantification of tannins in tree foliage. A laboratory manual for the FAO/IAEA co-ordinated research project on 'Use of Nuclear and Related Techniques to Develop Simple Tannin Assays for Predicting and Improving the Safety and Efficiency of Feeding Ruminants on Tanniniferous Tree foliage'. FAO/IAEA working document IAEA, VIENA (Austria), 26 p. https://www.researchgate.net/ publication/279349709.

Manolaraki, F. (2011). Propriétés anthelminthiques du sainfoin (Onobrychis viciifoliae): Analyse des facteurs de variations et du rôle des composés phénoliques impliqués. Thèse de Doctorat, INP Toulouse, Univ. Toulouse, France, 185 p. ULR : https://oatao.univ-toulouse.fr/7091/1/manolaraki.pdf

Meenakshisundaram A., Harikrishnan J.T., Anna T. (2017). Anthelmintic evaluation of Cucurbita pepo against gastrointestinal nematodes of sheep. Indian Journal of Animal Research. 51: 518-524. DOI : 10.18805/ijar.v0iOF.7264.

Mohanty, P.K., Chourasia, N., Bhatt, N.K. and Jaliwala, Y.A. (2011). Preliminary Phytochemical Screening of Cajanus cajan L. Asian J. Pharm. Tech. 1(2): 49-52. DOI: 10.5958/2231-5713.
Nguyen, M.T., Binh, V.D. and Orskov, R.E. (2005). Effect of foliages containing condensed tannins and on gastrointestinal parasites. Animal Feed Science and Technology. 121: 77-87. DOI: 10.1016/j.anifeedsci.2005.02.013.

Papadopoulos, E. (2008). Anthelmintic resistance in sheep nematodes. Small Ruminant Research. 76: 99-103. https://doi.org/ 10.1016/j.heliyon.2018.e00205.

Odeny, D.A. (2007). The potential of pigeon pea [Cajanus cajan (L.) Millsp.] in Africa. Natural Resources Forum. 31(4): 297-305. https://doi.org/10.1111/j.1477-8947.2007. 00157.x.

Quijada, J., Fryganas, C., Ropiak, H.M., Ramsay, A., Mueller-Harvey, I. and Hoste, H. (2015). Anthelmintic activities against Haemonchus contortus or Trichostrongylus colubriformis from small ruminants are influenced by structural features of condensed tannins. J. Agric. Food Chem. 63: 63466354. https://doi.org/10.1021/jf60158a601.

Sarkar, S., Panda, S., Yadav, K.K., Kandasamy, P. (2020). Pigeon pea (Cajanus cajan) an important food legume in Indian scenario- A review. Legume Research. (43): 601-610. DOI: $10.18805 / L R-4021$.

Sawargaonkar, L.S., Saxena, K. and Saxena, K.R. (2016). Overview of hybrid pigeonpea seed production technology and its on-farm validation. Plant Knowledge Journal. 5(1): 1317. URL, http://www.sciencej.com.

Singh, S., Mehta, A., John, J. and Mehta, P. (2010). Anthelmintic Potential of Andrographis paniculata, Cajanus cajan and Silybum marianum. Phcog J. 1(4): 243-245. DOI: 10.41 35/9788132104940.n3

Talari, A., Shakappa, D. (2018). Role of pigeon pea (Cajanus cajan L.) in human nutrition and health: A review. Asian Journal of Dairy and Food Research. 37: 212-220. DOI: 10.18805/ ajdfr.DR-1379.

Velay, F., Baudoin, J.-P. et Mergeai, G. (2001). Caractérisation du savoir paysan sur les insectes nuisibles du pois d'Angole [Cajanus cajan (L.) Millsp.] dans le Nord de l'Ouganda, Biotechnol. Agron. Soc. Environ. 5(2): 105-114. Available at: https://popups.uliege.be/1780-4507/index.php/base/ issue/index. php?id=17467 andfile=1 andpid $=14928$.

Williams, A.R., Fryganas C., Ramsay, A., Mueller-Harvey, I. and Thamsborg, S.M. (2014). Direct anthelmintic effects of condensed tannins from diverse plant sources against Ascaris suum. PLoS ONE 9(5): e97053. DOI:10.1371/ journal.pone.0097053. 